Technical method

\section{Serum glucose agar, a transport medium for Streptococcus pyogenes}

\author{
ELIZABETH M PERKS, RICHARD T MAYON-WHITE \\ Department of Microbiology, John Radcliffe Hospital, \\ Oxford
}

When planning an epidemiological study of streptococcal infection, we were recommended to try serum glucose agar which had proved a useful transport medium in another study. ${ }^{1}$ We compared serum glucose agar with Stuart's transport medium, which was our laboratory's usual transport medium for delicate organisms and with dry serum-coated swabs. We also considered the commercially available systems but found that none was sufficiently cheap and robust for our needs. This brief report describes our assessment of serum glucose agar made in our laboratory.

\section{Material and methods}

The transport media used in this study were (i) serum glucose agar, containing $0.5 \%$ glucose, $0.7 \%$ Noble Agar (Difco) and 5\% horse serum and (ii) Stuart's transport medium (Oxoid). These two semi-solid agar media were dispensed in $5 \mathrm{ml}$ volumes in bijoux bottles. In the study, swabs were snapped into the bottles. The dry serum-coated swabs were obtained from Medical Wire and Equipment Co Ltd. Blood agar was poured as a bilayer, using Columbia agar base (Oxoid) and 5\% horse blood. Todd-Hewitt broth (Difco) was used for initial cultures and preliminary dilutions were made in brain heart infusion broth (Oxoid).

In a test of the survival of Strep pyogenes in transport medium, sets of seven swabs inoculated from cultures were treated as follows:

1 Broken into serum glucose agar and stored at room temperature for $48 \mathrm{~h}$.

2 Broken into Stuart's transport medium and stored at room temperature for $48 \mathrm{~h}$.

3 Returned to the holder and stored dry at room temperature for $48 \mathrm{~h}$.

4 Broken into serum glucose agar and stored at $4^{\circ} \mathrm{C}$ for 7 days.
5 Broken into Stuart's transport medium and stored at $4^{\circ} \mathrm{C}$ for 7 days.

6 Returned to the holder and stored dry at $4^{\circ} \mathrm{C}$ for 7 days.

7 Inoculated onto blood agar immediately.

After storage, the swabs were inoculated onto blood agar. Inoculation was standardised by using six even strokes for each plate.

The number of organisms surviving was counted by starting with serial decimal dilutions of overnight cultures. Each dilution was sampled with a set of seven swabs. The dilutions giving between 20 and 200 colonies/plate were used to estimate the number of organisms present in the initial broth culture (swab 7) and on the swabs after storage (swabs 1-6). The multiplication or death of organisms was expressed as a growth index equal to the logarithm of (number of organisms after storage divided by the initial count). Thus multiplication of organisms gave a positive growth index whilst a negative index indicated cell death.

The cultures tested were 25 strains of Streptococcus pyogenes in pure culture, the same 25 strains of Strep pyogenes mixed with the normal throat flora of one person, and one strain of Strep pyogenes in 10 different cultures of normal flora.

An opportunity to compare serum glucose agar with direct inoculation of blood agar arose in the investigation of a school outbreak of scarlet fever. One hundred and sixty-three pairs of throat swabs were taken from pupils and staff. The first swab in each pair was inoculated onto blood agar immediately; the second was snapped into serum glucose agar and left overnight at room temperature before subculturing onto blood agar. The blood agars were incubated anaerobically at $37^{\circ} \mathrm{C}$ overnight. Betahaemolytic streptococci were grouped by Lancefield's method, and the findings of Strep pyogenes were analysed.

\section{Results}

The results of the comparison between serum glucose agar, Stuart's transport medium and dry serumcoated swabs are shown in Table 1. Storage of Strep pyogenes on dry serum-coated swabs consistently resulted in cell death (negative growth index) at both temperatures and in the presence of normal flora. Growth indices of swabs stored in serum glucose agar and Stuart's transport medium were consistently lower in the presence of normal flora. However, multiplication of organisms occurred in both serum 
Table 1 Means (and standard deviation) of growth indices under different conditions

\begin{tabular}{|c|c|c|c|c|c|c|}
\hline \multirow[b]{3}{*}{ Cultures } & \multicolumn{6}{|c|}{ Storage conditions } \\
\hline & \multicolumn{3}{|c|}{ Room temp for $48 h$} & \multicolumn{3}{|c|}{$4^{\circ} \mathrm{C}$ for 7 days } \\
\hline & $S G A$ & $S T M$ & $D R Y$ & $S G A$ & STM & $D R Y$ \\
\hline $\begin{array}{l}25 \text { strains of Strep pyogenes alone } \\
25 \text { strains of Strep pyogenes in } \\
\text { normal flora } \\
1 \text { strain of Strep pyogenes in } \\
10 \text { cultures in normal flora }\end{array}$ & $\begin{array}{l}4 \cdot 0 \\
( \pm 1 \cdot 7) \\
2 \cdot 8 \\
( \pm 0 \cdot 7) \\
3 \cdot 7 \\
( \pm 0 \cdot 7)\end{array}$ & $\begin{array}{l}2 \cdot 9 \\
( \pm 2 \cdot 0) \\
1 \cdot 9 \\
( \pm 0 \cdot 8) \\
3 \cdot 1 \\
( \pm 1 \cdot 1)\end{array}$ & $\begin{array}{l}-0.6 \\
( \pm 0.7) \\
-0.3 \\
( \pm 0.7) \\
-0.4 \\
( \pm 0.7)\end{array}$ & $\begin{array}{l}3 \cdot 4 \\
( \pm 2 \cdot 0) \\
0 \cdot 9 \\
( \pm 0 \cdot 7) \\
3 \cdot 5 \\
( \pm 1 \cdot 1)\end{array}$ & $\begin{array}{l}2 \cdot 6 \\
( \pm 1 \cdot 7) \\
0 \cdot 2 \\
( \pm 0 \cdot 7) \\
2 \cdot 7 \\
( \pm 1 \cdot 4)\end{array}$ & $\begin{array}{l}-1 \cdot 6 \\
( \pm 0 \cdot 7) \\
-0.8 \\
( \pm 0 \cdot 8) \\
-0.2 \\
( \pm 0.8)\end{array}$ \\
\hline
\end{tabular}

SGA = Swabs in serum glucose agar.

STM $=$ Swabs in Stuart's transport medium.

DRY = Dry serum-coated swabs.

Table 2 Isolation of Strep pyogenes from throat swabs in school outbřeak

\begin{tabular}{llcc}
\hline & \multicolumn{3}{l}{ Immediate } \\
\cline { 2 - 4 } & Positive & Negative & Total \\
\hline Serum glucose agar-positive & 27 & 11 & 38 \\
Serum glucose agar-negative & 5 & 120 & 125 \\
Total & 32 & 131 & 163 \\
\hline
\end{tabular}

glucose agar and Stuart's transport medium in all the conditions tested.

Of the 163 paired throat swabs examined, 27 yielded group A streptococci in both cultures and 120 were negative by both methods (Table 2). In the 16 cultures with disagreement between the two methods, there were less than 10 colonies of group A streptococci on the plates of positive cultures.

\section{Discussion}

We have found that serum glucose agar met our needs for a streptococcal transport medium. In the laboratory, it gave isolation rates significantly higher than Stuart's transport medium or dry serum-coated swabs. As shown by the positive growth index, serum glucose agar serves as an enrichment medium at room temperature. This property is useful in surveys for streptococcal carriers who may have few organisms. In the investigation of the outbreak, we found that swabs left in serum glucose agar overnight were as good as swabs plated immediately. However, we would point out that incubation of serum glucose agar at $37^{\circ} \mathrm{C}$ causes a decline in streptococcal numbers, presumably nutrients are quickly exhausted. Another advantage of using serum glucose agar was its low cost. The system of swabs snapped into semi-solid agar in small bottles is easier than agar plates for field work. In some preliminary experiments, we found that the screw-top bijoux bottles were stronger and less likely to leak than the commercial transport swabs. Having assessed serum glucose agar in the laboratory, we used it in a survey of scarlet fever in which specimens were sent through the post. ${ }^{2} \mathrm{We}$ found no problems in practice. Although other pathogens were not the main object of our study, we found that other respiratory bacteria could survive in serum glucose agar. In summary, our experience confirms the observations of Colling et $a^{1}$ that serum glucose agar is a useful enrichment medium for Streptococcus pyogenes in throat swabs.

This study formed part of an MSc degree in medical microbiology, awarded to EM Perks by the University of Surrey.

\section{References}

${ }^{1}$ Colling A, Kerr I, Maxted WR, Widdowson JP. Streptococcal infection in a junior detention centre: a five year study. $J$ Hyg (Camb) 1980;85:331-41.

${ }^{2}$ Perks EM, Mayon-White RT. The incidence of scarlet fever. J Hyg (Camb) 1983; (in press).

Requests for reprints to: Dr R Mayon-White, Microbiology Laboratory, John Radcliffe Hospital, Headington, Oxford OX3 9DU. 